\title{
CORRECTIONS
}

\section{Investigating hyponatraemia}

In the opening section ("The patient") of this Rational Testing article by Ammar Wakil and colleagues (BMJ 2011;342:d1118, doi:10.1136/bmj.d1118) the units for the serum creatinine concentration were wrong: the text should have said "creatinine $55 \mu \mathrm{mol} / \mathrm{L}(51-107 \mu \mathrm{mol} / \mathrm{L})$ " [not $55 \mathrm{mmol} / \mathrm{L}$ (51-107 mmol/L)].

Cite this as: $B M J$ 2011;342:d2401 